\title{
Computer Anxiety and Use of Online Resources by Distance Learning Students in Two Universities in Oyo State, Nigeria
}

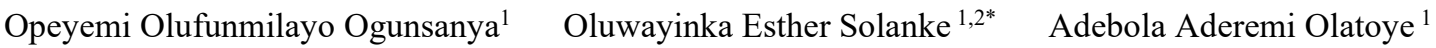 \\ 1.Department of Library, Archival and Information Studies, University of Ibadan, Ibadan, Nigeria \\ 2.University of Medical Science, Ondo, P.M.B 536 Ondo State, Nigeria
}

\begin{abstract}
The purpose of this study is to examined computer anxiety and use of online resources by distance learning students in two universities in Oyo State Nigeria. Online resources are important for distance learning students in their academic pursuit but anxiety about the use of computer can pose a major setback to their pursuit of excellence in academic especially as Distance Learning Students (DLS). However, not much focus has been given to a study as this in Nigeria. Descriptive survey design was adopted using a questionnaire as instrument for data collection. Multistage sampling technique was used to sample 270 respondents. Five (5) research questions and one (1) hypothesis were developed to guide the study. The results show that distance learning students from both universities use online resources for educational purposes and general knowledge, positive relationship between computer anxiety and online resources. The study recommends that universities should subscribe for more relevant online resources for the benefit of their students, who desire to use relevant online resources but are hindered by cost and technical issues.
\end{abstract}

Keywords: Computer Anxiety, Online Resources, Distance Learning Students, Universities

DOI: $10.7176 / \mathrm{IKM} / 10-2-02$

Publication date: February $29^{\text {th }} 2020$

\section{Introduction}

Universities as academic institutions serve as engines of economic development. A university has the capability to generate economic benefits for its host community through local purchases, property investments and expenditures by the students, visitors and institution itself. The students that are studying in the universities are divided into two categories namely; the full time students and the distance learning students. It was as a result of satisfying the academic needs of individuals who wish to acquire formal education irrespective of their jobs that distance learning programmes came to the fore of universities (Altbach, 2007).

Distance learning can be defined as the institution-based, formal education where the learning group is separated, and where interactive telecommunication systems are used to connect learners, resources and instructors (Schlosser and Simonson, 2006). Adetimirin and Omogbhe (2011) stated that distance learning is often described as the formalized learning received while the student is on location outside the campus. The teacher and students are expected to have minimal physical contact, but much reliance on electronic communication and independent studying.

Adetimirin and Omogbhe (2011) quoting Akintayo and Bunza (2000) stated that distance learning students have characteristics which include: adults with professional responsibilities (jobs), social responsibilities (families), study part time, limited formal education or are a longtime away from formal education, highly and intrinsically motivated and who are interested in practical results for career, occupation or lifestyle. Others include clear cut goals, self-directed, study on independent basis, learn in a variety of ways, take control over their learning and often experience a feeling of isolation and remoteness from other students. Studies conducted on information source of distance learning students in Pew Internet and American Life Project and Online Computer Library Centre, which revealed that the selected distance learning students use the internet as their primary source of academic-related information, the researchers also added that print sources use by distance learning students include; books, journal articles, newspapers, theses, dissertations, proceedings, white papers and technical reports (Edwards, 2006).

According to Nwogu and Anunobi, 2007 and Anunobi and Mbagwu, 2009 distance learning students use the online resources for school related activities such as search for materials needed for assignment, research, teaching and class work. Although, the use of online resources has been embraced by majority of the distance learning students, yet there are various problems militating against the use of online resources by the distance learning students.

The study focuses on factors affecting the use of online resources by distance learning students in two universities in Oyo State, Nigeria namely: distance learning centre University of Ibadan and National Open University of Nigeria, Oyo State campus. The study will cover computer anxiety as a factor. Some online resources to be studied are Online Public Access Catalogue (OPAC), e-journals, e-reference, library websites, online databases and online reference sources. One of the major factors militating against the use of online resources by distance learning students adopted from technology acceptance model (TAM3) is computer anxiety. 
Olatoye (2009) defined computer anxiety as the fear impending interaction with a computer that is disproportionate to the actual threat presented by the computer. Buche Davis and Vician, (2007) opined that students computer anxiety could be lowered with positive online experience and not just mere exposure to online resources.

\section{Research Problem}

In developing countries, such as Nigeria, distance education in universities is not accompanied with the adequate use of online resources because of the developing nature of information and communication technology in Nigeria. Most distance learning students in Nigerian universities do not make maximum use of online resources in the course of their learning programmes. Scholars have carried out researches on distance learning students and use of online resources. Still there is a gap this study intend to fill; which is the factors affecting use of online resources by distance learning students. It is noted from the Technology Acceptance Model 3 (TAM3) that Computer Anxiety is basically a factor. This study examines how anxiety can affect distance learning students on the use of online resources in Nigerian universities.

\section{Research Questions}

The study is set to provide answers to the research questions derived from general and specific objectives as underlisted.

1. What are the various types of online resources use by distance learning students?

2. How frequently do distance learning students use online resources?

3. What are the purposes of using online resources by distance learning students?

4. What is computer anxiety of distance learning students in their use of online resources?

5. What are the challenges faced by distance learning students in their use of online resources?

\section{Hypothesis}

$\mathrm{Ho}_{1}$ : There is no significant relationship between computer anxiety and use of online resources.

\section{Literature Review}

\subsection{Computer anxiety of distance learning students}

Computer anxiety is defined as the inclination of an individual to have a negative reaction while considering computer usage (Saade \& Kira, 2009). These include positive and negative beliefs, about computers, insecurity, nervousness, apprehension, fear, intimidation and hesitation. Negative emotions associated with the computer use can affect the overall learning experience. Frustration, confusion, anger, anxiety and similar emotional states can affect not only the interaction itself, but also productivity, learning, social relationships, and overall wellbeing (Saade and Kira 2007). Distance students with high computer anxiety will see using online resources for learning as a difficult task. Research has shown students with high level of computer anxiety are at a disadvantage compared to students with lower anxiety levels (Saade and Kira, 2007). Students with high computer anxiety experience several type of problem ranging from frustration, confusion and anxiety. Many instructors expect students to interact frequently with online resources and with one another using information and communication technology. For these students, the fear of using online resources may be compounded.

Koroboli, Togia and Malliari (2010) reported that computer anxiety was correlated positively with PC ownership, access to online resources and frequency of online resource use. Distance learning students are expected to use online resources to perform research for their course assignments. Ng, Yeung, and Hon (2006) stated that it seems logical that students who are less skilled will have more anxiety that will lessen their use of online resources. Collins and Veal (2004) found that students with the highest level of computer anxiety had a negative self-perception of his/her ability to access online resources using the internet for research. Know, Onwuegbuzie and Alexander (2007) found a link between students' depositions towards critical thinking led to a higher level of computer anxiety. Venkatesh and Bala (2008) reported that the effect of computer anxiety on online resources will decline with increasing experience as students will have more accurate perception of the effort needed to use online resources.

\subsection{Use of online resources by distance learning students}

The use of electronic resources by distance students in Nigeria majorly centre round the use of cybercafé and the University library in order to gain access to the online resources. Damilola (2013) reported that majority of the students to a great extent made use of available online resources mostly for knowledge acquisition and learning purposes, information exchange and project write up.

Babalola and Babalola (2014) in their study of the use of information and communication technologies among distance learning students of the University of Ibadan, Nigeria submitted that $17.0 \%$ of the students used online resources for educational purposes such as obtaining information and materials to do assignment, $86.2 \%$ 
of the students indicated that they used online resources for academic purpose especially to do their assignments.

\subsection{Technology Acceptance Model 3}

Students perception of e-learning in University education may be influenced by several variables (Keller and Cerneinua 2002) have identified variables such as age, gender, previous experience and computers, technology acceptance and individual learning styles as major predictive factors when discussing acceptance of technology by students. The theoretical framework for this study is based on some conclusions drawn from Technology Acceptance Model 3 (TAM) and this is computer anxiety. The Technology Acceptance Model (TAM) was developed by Davis to explain computer-usage behavior (Davis, 1989). The goal of TAM is "to provide an explanation of the determinants of computer acceptance that is general, capable of explaining user behavior across a broad range of end-user computing technologies and user population which at the same time being both parsimonious and theoretically justified" (Davis, 1986; Davis Bagozzi, and Warshaw, 1989).

\subsection{Conceptual Framework}

Students engage in learning and therefore, will always source for information to accomplish these learning tasks. The type of information needed would lead to seeking information from many sources as print and non-print materials (online resources) located in different places on the net.

The study therefore proposes that this factor (computer anxiety) which is independent variables could affect the use of online resources (dependent variables) by distance learning students.

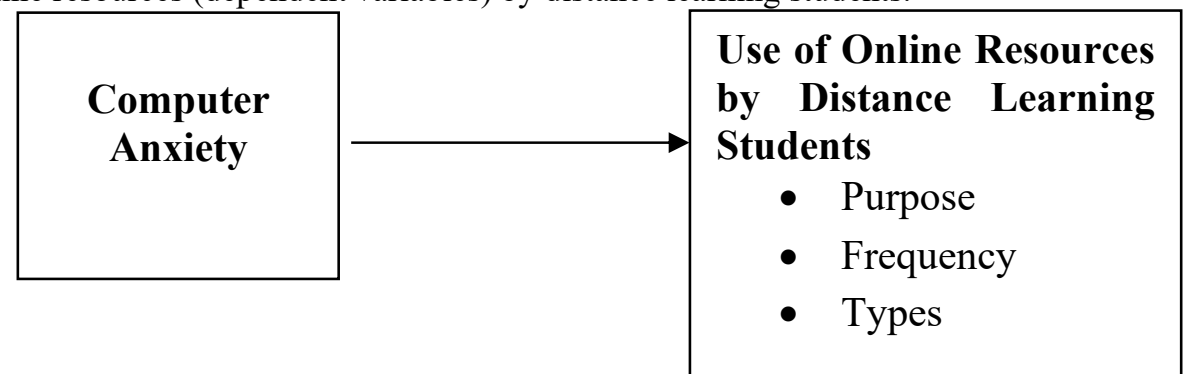

Figure 1: Self Developed Conceptual Frame Work

\section{Methodology}

This study adopted survey design, the population of this study consisted of distance learning students of University of Ibadan and National Open University of Nigeria (Ibadan Study Centre). The total population of Distance Leaning Student in University of Ibadan was 16,275 and 8,294 in National Open University respectively. The study adopted a multistage sampling technique to select the sample size. Multistage is a sampling method in which the population is divided into number of groups or primary stages from which samples are drawn. The reason for using multistage was because each faculty/school had a large number of students, and also to select faculties/schools that are peculiar to both universities.

Therefore, by means of multistage sampling, three faculties/ schools were selected randomly from both universities. The faculties/schools are; Social Science, Arts and Education. From each faculties/schools, two departments were selected randomly. From each departments probability proportionate to size sampling method was used to select the students. A sample fraction of $2 \%$ for distance learning students of the University of Ibadan and the National Open University of Nigeria, Ibadan study centre was used to get a sample size of 270. The data collection instrument was validated to ensure both content and construct validity and data analysis and hypothesis testing was done in an SPSS output format. 
6.1 Sample Size of the Study

Table 1: Sample Size of the Study

\begin{tabular}{|l|l|l|l|}
\hline Faculties in UI,DLC & Departments & Population of Students & $\mathbf{2 \%}$ Sample \\
\cline { 2 - 4 } & Communication and Language Art & 625 & 13 \\
\cline { 2 - 4 } & French & 50 & 1 \\
\hline \multirow{2}{*}{ Education } & Educational Management & 404 & 8 \\
\cline { 2 - 4 } & Guidance Counseling & 1741 & 35 \\
\hline \multirow{2}{*}{ Total } & Psychology & 2960 & 59 \\
\cline { 2 - 4 } & Economics & 3687 & 74 \\
\hline Schools in NOUN & & & $\mathbf{1 9 0}$ \\
\hline \multirow{2}{*}{ Edts } & Departments & Population of Students & $\mathbf{2 \%}$ Sample \\
\hline \multirow{2}{*}{ Social Science } & Criminology and security studies & 718 & 14 \\
\cline { 2 - 4 } & Peaces Studies and Conflict Resolution & 437 & 9 \\
\hline Total & Business Education & 187 & 4 \\
\cline { 2 - 4 } & Biology & 69 & 1 \\
\cline { 2 - 4 } & Eccounting & 588 & 12 \\
\hline & & 2006 & 40 \\
\hline
\end{tabular}

\subsection{Data Analysis}

The data analysis method that was used was descriptive statistical measures such as percentages and frequency distribution which showed the questionnaire response rate. The Statistical Package for Social Science (SPSS) was used for the analysis. Descriptive statistics such as percentages mean and standard deviation was used to provide answers to research questions. Pearson correlation was used to analyse the hypotheses.

\section{Result and Discussion}

A total of 190 questionnaire designed for the study were administered to the selected distance learning students in University of Ibadan, Ibadan and 80 copies of questionnaire learning students in National Open University of Nigeria, Ibadan, Nigeria. However, only 178(93.7\%) in University of Ibadan and $76(95 \%)$ copies in National Open University of Nigeria were returned with useful responses sequel to completion by the respondents.

Research Question One: What are the various types of online resources used by distance learning students? The result shows that in University of Ibadan, 65(52.4\%) in Social Sciences and 7(50.0\%) in Arts used Lecture materials/ teachers guides daily. Hence, 18(45.0\%) in Education used Lecture materials/ teachers guides weekly. Similarly, 63(50.8\%) in Social Sciences used Electronic Databases daily, while 10(71.4) in Arts and 16(40.0\%) in Education used Electronic Databases weekly. However, only 81(65.3\%) in Social Sciences used E-Journals weekly. Also, only 64(51.6\%) in Social Sciences used OPAC/WEBPAC. Result shows that in National Open University of Nigeria, 17(73.9\%) in Arts, and 25(52.1\%) in Social Sciences used Lecture materials/ teachers guides daily, meanwhile $3(60.0 \%)$ in education ticked weekly. Also, 36(75.0\%) in Social Sciences, 3(60.0\%) in Education used online reference sources weekly, hence 11(47.8\%) in Arts used online reference sources daily. Only 11(47.8\%) in Arts used E- Documents daily. And 23(47.9\%) in Social Sciences used OPAC/WEBPAC weekly. Based on the findings, central to both universities under study, the various types of online resources used by distance learning students include: Lecture materials/ teachers guides, online reference sources, and Electronic Databases.

Research Question Two: How frequently do distance learning students use online resources?

The result shows that in University of Ibadan, 65(52.4\%) in Social Sciences and 7(50.0\%) in Arts used Lecture materials/ teachers guides daily. Hence, $18(45.0 \%)$ in Education used Lecture materials/ teachers guides weekly. Similarly, 63(50.8\%) in Social Sciences used Electronic Databases daily, while 10(71.4) in Arts and 16(40.0\%) in Education used Electronic Databases weekly. However, only 81(65.3\%) in Social Sciences used E-Journals weekly. Also, only 64(51.6\%) in Social Sciences used OPAC/WEBPAC. In National Open University of Nigeria, $17(73.9 \%)$ in Arts, and 25(52.1\%) in Social Sciences used Lecture materials/ teachers guides daily, meanwhile $3(60.0 \%)$ in education ticked weekly. Also, 36(75.0\%) in Social Sciences, 3(60.0\%) in Education used online reference sources weekly, hence 11(47.8\%) in Arts used online reference sources daily. Only 11(47.8\%) in Arts used E-Documents daily. And 23(47.9\%) in Social Sciences used OPAC/WEBPAC weekly. Based on this findings, central to both universities under study, the distance learning students used lecture materials/ teachers guides almost daily. Also, the respondents used online reference sources and Electronic Databases at least weekly.

Research Question Three: What are the purposes of using online resources by distance learning students?

Findings show that in University of Ibadan, 39(97.5\%) in Education, 12(85.7\%) in Arts and 102(82.3\%) in 
Social Sciences used online resources for educational purpose. Similarly, $8(57.1 \%)$ in Arts, 22(55.0\%) in education and 65(52.4\%) in Social Sciences used online resources for general knowledge. Hence, only 11(78.6\%) in Arts used online resources for reading News on academic programme. In the same way, 11(78.6\%) in Arts used online resources Project write-up.

Also in National Open University of Nigeria, 42(87.5\%) in Social Sciences, 20(87.0\%) in Arts and 4(80.0\%) in Education used online resources for educational purpose. Similarly, 17(73.9\%) in Arts, 3(60.0\%) in education and 25(52.1\%) in Social Sciences used online resources for general knowledge. However, only 14(60.9\%) in Arts used online resources for reading News on academic programme. In the same way, 15(65.2\%) in Arts used online resources Project write-up. It is evident that in both universities under study, distance learning students used online resources for major purposes such as educational purposes and general knowledge. Hence, the students (especially in the Faculty of Arts) also used online resources for minor purposes such as: academic discussion, News on academic programme, information exchange, and assignments.

Table 7.1: Purposes of using online resources by distance learning students

Key: Frequency (F) Percentage (\%)

\begin{tabular}{|c|c|c|c|c|c|c|c|c|c|c|c|c|c|}
\hline \multirow[t]{3}{*}{$\mathbf{S} / \mathbf{N}$} & \multirow[t]{3}{*}{ Purposes } & \multicolumn{6}{|c|}{ University of Ibadan (UI) } & \multicolumn{6}{|c|}{$\begin{array}{l}\text { National Open University of Nigeria } \\
\text { (NOUN) }\end{array}$} \\
\hline & & \multicolumn{2}{|c|}{$\begin{array}{l}\text { Faculty } \\
\text { of Arts }\end{array}$} & \multicolumn{2}{|c|}{$\begin{array}{l}\text { Faculty of } \\
\text { Education }\end{array}$} & \multicolumn{2}{|c|}{$\begin{array}{l}\text { Faculty of } \\
\text { Social } \\
\text { Sciences }\end{array}$} & \multicolumn{2}{|c|}{$\begin{array}{l}\text { Faculty } \\
\text { of Arts }\end{array}$} & \multicolumn{2}{|c|}{$\begin{array}{l}\text { Faculty of } \\
\text { Education }\end{array}$} & \multicolumn{2}{|c|}{$\begin{array}{l}\text { Faculty of } \\
\text { Social } \\
\text { Sciences }\end{array}$} \\
\hline & & $\mathbf{F}$ & $\%$ & $\mathbf{F}$ & $\%$ & $\mathbf{F}$ & $\%$ & $\mathbf{F}$ & $\%$ & $\mathbf{F}$ & $\%$ & $\mathbf{F}$ & $\%$ \\
\hline a. & Seminar papers & 6 & 42.9 & 20 & 50.0 & 54 & 43.5 & 9 & 39.1 & 3 & 60.0 & 18 & 37.5 \\
\hline b. & $\begin{array}{l}\text { Academic } \\
\text { discussion }\end{array}$ & 8 & 57.1 & 22 & 55.0 & 65 & 52.4 & 20 & 87.0 & 4 & 80.0 & 23 & 47.9 \\
\hline c. & $\begin{array}{l}\text { General } \\
\text { Knowledge }\end{array}$ & 8 & 57.1 & 21 & 52.5 & 70 & 56.5 & 17 & 73.9 & 3 & 60.0 & 25 & 52.1 \\
\hline d. & $\begin{array}{ll}\text { News } & \text { on } \\
\text { academic } & \\
\text { programme } & \\
\end{array}$ & 11 & 78.6 & 16 & 40.0 & 54 & 43.5 & 14 & 60.9 & 2 & 40.0 & 18 & 37.5 \\
\hline e. & Project write-up & 11 & 78.6 & 14 & 35.0 & 32 & 25.8 & 15 & 65.2 & 2 & 40.0 & 18 & 37.5 \\
\hline f. & Assignments & 10 & 71.4 & 22 & 55.0 & 48 & 38.7 & 20 & 87.0 & 3 & 60.0 & 12 & 25.0 \\
\hline g. & $\begin{array}{l}\text { Information } \\
\text { exchange }\end{array}$ & 10 & 71.4 & 14 & 35.0 & 22 & 17.7 & 17 & 73.9 & 2 & 40.0 & 18 & 37.5 \\
\hline h. & $\begin{array}{l}\text { Educational } \\
\text { purposes }\end{array}$ & 12 & 85.7 & 39 & 97.5 & 102 & 82.3 & 20 & 87.0 & 4 & 80.0 & 42 & 87.5 \\
\hline
\end{tabular}

Research Question Four: What is the computer anxiety of distance learning students in their use of online resources?

Result shows that in University of Ibadan, 65(52.4\%) in Social Sciences, 8(57.1\%) in Arts and 23(57.5\%) in Education agreed that the challenge of using online resources is exciting. Also, 63(50.8\%) in Social Sciences and $22(55.0 \%)$ in education strongly agreed, and 8(57.1\%) in Arts agreed that using online resources is like learning a new skill. However, only $7(50.0 \%)$ in Arts agreed that they hesitate to use online resources for fear that they might not get the necessary references needed. Similarly, only 7(50.0\%) in Arts agreed that online resources are somehow intimidating to them. In National Open University of Nigeria, shows that 14(60.9\%) in Arts agreed, $3(60.0 \%)$ in Education agreed and 22(45.8\%) in Social Sciences strongly agreed that using online resources is like learning a new skill. Also, 14(60.9\%) in Arts agreed, 2(40.0\%) in Education agreed and 23(47.9\%) in Social Sciences agreed that the challenge of using online resources is exciting. Hence, only $24(50.0 \%)$ in Social Sciences agreed that they feel apprehensive about using online resources. And 28(58.3\%) in Social Sciences agreed that they feel they will be able to keep up with the everyday advancement of online resources.

Therefore, one can easily conclude that the computer anxiety of the students in both universities included: feeling insecure for using online resources for academic work, the feel that using online resources is like learning new skill, the feel that sourcing for online resources are too cumbersome to understand and the fear of inability to keep up with the everyday advancement of online resources.

Research Question Five: What are the challenges faced by distance learning students in their use of online resources?

Based on findings, University of Ibadan, 70(56.5\%) respondents in Social Sciences agreed, 7(50.0\%) respondents in Arts agreed and $22(55.0 \%)$ in Education strongly agreed that printing online resources is expensive. Also, 21(52.5\%) in Education agreed, 81(65.3\%) in Social Sciences agreed and 5(35.7\%) in arts agreed that inadequate availability of online resources is a challenge. Only 61(49.2\%) respondents in Social Sciences agreed that non-subscription for relevant online resources by institutions is a challenge. And, 25(62.5\%) 
in Education strongly disagreed that downloading online resources is difficult. In National Open University of Nigeria, shows that 3(60.0\%) respondents in Education agreed, 25(52.1\%) respondents in Social Sciences agreed and 9(39.1\%) respondents in Arts agreed that printing online resources is expensive. Only 3(60.0\%) in Education agreed that high cost of access and usage of online resources is a challenge to the use of online resources. And $22(45.8 \%)$ in Social Sciences agreed that Inadequate requisite skills is a challenge.

Based on the results one can say that in both universities, inadequate telecommunication facilities, unstable power supply to access online resources and high cost of printing online resources are peculiar challenges faced by distance learning students in their use of online resources.

\section{Testing the Research Hypotheses}

The research hypothesis was tested at 0.05 level of significance. There is no significant relationship between computer anxiety and use of online resources. Table 8.5 shows the correlation between computer anxiety and use of online resources. In University of Ibadan, there is insignificant positive but weak correlation $(\mathrm{r}=0.082 ; \mathrm{P}$ $<.05)$. Similarly, there is a positive significant but weak correlation $\left(\mathrm{r}=0.365^{* *} ; \mathrm{P}<.05\right)$ in National Open University of Nigeria. Thus positive relationships exist between computer anxiety and use of online resources in both universities but the correlation is only significant in National Open University of Nigeria and not significant in University of Ibadan.

Table 7.5: Relationship between Computer Anxiety and Use of Online Resources

\begin{tabular}{l|cccccccc}
\hline University & Variables & Mean & Std. Deviation & $\mathbf{N}$ & $\mathbf{r}$ & Df & Sig.P & Remarks \\
\hline & UI CA & 41.28 & 7.269 & 178 & $.082^{* *}$ & 177 & .274 & Not Significant \\
& U.OR & 22.72 & 7.704 & 178 & & & & \\
\hline N.O.U.N & CA & 40.80 & 8.206 & 76 & $.365^{* 8}$ & 75 & .001 & Significant \\
U.O.R & 21.28 & 8.555 & 76 & & & & & \\
\hline
\end{tabular}

*significant at $\mathrm{p}<.05, \mathrm{CA}$ : computer anxiety, U.O.R: use of online resources

\section{Conclusion and Recommendations}

This study investigated computer anxiety and use of online resources by distance learning students of two universities, Ibadan Nigeria. The results generally showed that distance learning students used lecture materials/ teachers' guides, online reference sources, and Electronic Databases were found to be types of online resources available to distance learning students in both universities. While other online resource such as online discussion group were found to be rarely available to distance learning students in Faculty of Education in University of Ibadan. Most of the distance learning students in both universities used lecture materials/ teachers guides almost daily. The respondents used online reference sources and Electronic Databases at least weekly. Respondents from both universities used online resources for major purposes such as educational purposes and general knowledge.

The respondents (especially in the Faculty of Arts) also used online resources for minor purposes such as: academic discussion, News on academic programme, information exchange, and assignments. Anxiety of the distance learning in the two universities include: feeling insecure for using online resources for academic work, the feel that using online resources is like learning new skill, the feel that sourcing for online resources are too cumbersome to understand and the fear of inability to keep up with the everyday advancement of online resources. The challenges faced by distance learning students in both universities are, inadequate telecommunication facilities, unstable power supply to access online resources and high cost of printing online resources. Positive relationships exist between computer anxiety and use of online resources in both universities but the correlation is only significant in National Open University of Nigeria.

The following recommendations are therefore made based on the findings of the study:

1. Infrastructure, including an adequate power supply, for the effective application of online resources in the university should be put in place and should not be limited to urban areas. This will enable distance learners in rural areas to benefit from modern technology.

2. Universities should subscribe for more relevant online resources such as JSTOR and EBSCOHOST, for the benefit of their students, who desire to use relevant online resources but are hindered by cost and technical issues.

3. Government and other stakeholders should advance and support the use of online resources and develop distance education programs of the highest quality. 


\section{References}

Altbach, Philip G. 2007. Academic Freedom: International Realities and Challenges. In: Altbach, P.G. Tradition and Transition: The International Imperative in Higher Education. Rotterdam, Netherlands: Sense Publishers. 49-66.

Adetimirin, A.E. and Omogbhe, G. 2011. Library Habits of Distance Learning Students of the University of Ibadan, Ibadan Oyo State, Nigeria: Library Philosophy and Practice. http://unllib.uni.edu/LPP/.

Agber, T. and Agwu, E. A. 2013. Assessment of Online Resources Usage by Agricultural Science Lecturers of Tertiary Institutions in Benue State, Nigeria. American Journal of Research Communication.1.10: 254-279. www.usa-journals.com.

Anunobi, C.V. and Mbagwu, F.C. 2009. Determinants of Internet Use in Imo State, Nigeria. Educational Research and Review.4.9:436-442. Retrieved on 11 Nov. 2014 from: http://www.academicjournals.org/err.

Babalola, O.A. and Babalola, F.D. 2014. The Use of Information and Communication Technologies among Distance Learning Students of the University of Ibadan, Nigeria: Covenant Journal of Communication (CJOC). 2. 1.

Buche, M., Davis, L., and Vician, C. 2007. A Longitudinal Investigation of the Effects of Computer Anxiety on Performance in a Computing-Intensive Environment. Journal of Information Systems Education. 18.4: $415-$ 423.

Damilola, O.A. 2013. Use of Electronic Resources by Distance Students in Nigeria: a Case Study of National Open University, Lagos and Ibadan study centers. Library Philosophy and Practice (e-journal). Paper 915. http://digitalcommons.unl.edu/libphilprac/915.

Davis, F. D. 1989. Perceived Usefulness, Perceived Ease of Use, and User Acceptance of Information Technology. MIS Quarterly 13.3: 319-339.

Davis, F.D., Bagozzi, R.P., and Warshaw, P.R. 1989. User acceptance of computer technology: A comparison of two theoretical models. Management Science. 35.8:982-1003.

Keller, C. and Cernerud, L. 2002. Students' perception of e-learning in university education. Journal of Educational Media. 27.1/2:55-65.

Kwon N., Onwuegbuzie A. J. and Alexander L. 2007. "Critical Thinking Disposition and Library Anxiety: Affective Domains on the Space of Information Seeking and Use in Academic Libraries", College \& Research Libraries.68. 3: pp. 268-278.

Koroboli, S., Togia, A., and Malhari, A. 2010. Computer anxiety and attitudes among undergraduate students in Greece. Computers in Human Behavior. 26.3:399-405.

Ng, C., Yeung, A.S., and Hon, R.Y.H. 2006. Does Online Language Learning Diminish Interaction between Student and Teacher? The Hong Kong Institute of Education. 43.3: 219-232.

Olatoye, R.F. 2009. Influence of Computer Anxiety and Knowledge on Computer Utilization of Secondary School Students, Nigeria: Electronic Journal of Research in Educational Psychology. 7.3: 1269-1288 19.ISSN:1696-2095.

Saade, R., and Kira, D. 2007. Mediating the Impact of Technology Usage on Perceived Ease of Use by Anxiety. Computers \& Education. 49.4: 1189-1204.

Saade, R., and Kira, D. 2009. Computer Anxiety in E-Learning: the Effect of Computer Self-Efficacy. Journal of Information Technology Education. 8: 177-191. Retrieved from http://www.jite.org/documents/vol18/JITEv8p177-191saade724.pdf

Schlosser, L., and Simonson, M. 2006. Distance Education: Definition and Glossary of Terms 2nd ed. Charlotte, NC: Information Age Publishing.

Thanuskodi, S. 2011. Internet Use among Distance Learners in the Changing Higher Education Environment at Bharathiar University, India. International Research Journal of Library, Information Archival Studies. 1.1: 023-029. Available online http://www.interesjournals.org/IRJLIAS

Venkatesh, V. and Bala, H. 2008. Technology acceptance model 3 and a research agenda on interventions. Decision sciences. 